\title{
THE EFFECT OF BUDGETS' PROPORTION AND NON-FINANCIAL FACTORS ON THE AUDIT RESULTS OF LOCAL GOVERNMENTS' FINANCIAL STATEMENTS IN INDONESIA
}

\author{
Nurdiono \\ Faculty of Economics and Business, Universitas Lampung, Indonesia \\ (nurdionopb@gmail.com) \\ Slamet Sugiri \\ Faculty of Economics and Business, Universitas Gadjah Mada \\ (ssugiri@feb.ugm.ac.id) \\ Abdul Halim \\ Faculty of Economics and Business, Universitas Gadjah Mada \\ (abhalim58@yahoo.com) \\ Gudono \\ Faculty of Economics and Business, Universitas Gadjah Mada \\ (gudono@feb.ugm.ac.id)
}

\begin{abstract}
Local governments' financial statements that obtain unqualified opinion until the end of 2011 were still relatively few in number. This study aims to empirically examine the effect on the audit results of the financial statements of local governments in Indonesia of the budgets' proportion, the effectiveness of the internal audit, the follow-up to the Supreme Audit Board's findings, the Supreme Audit Board's opinions from earlier periods, and the competence of the available human resources to understand the audit results of the Supreme Audit Board. Budget management has become very important since it lays out a detailed plan for the expenditure and revenue of the local governments, so that it can be accountable to the public.

This study used a sample of 434 Indonesian Local Governments' financial statements of 2011 and a logistic regression analysis. This study used primary and secondary data to uncover the phenomena that the local governments' financial statements which received an unqualified opinion from the Supreme Audit Board were still relatively few in number. The results of this study showed that the budgets' proportions of local governments are negatively significant in affecting the audit results of the financial statements of the local governments. The Supreme Audit Board's opinions from earlier periods positively influenced the audit results of the financial statements of local governments. Whereas the variables of the effectiveness of internal controls, the follow-up to the Supreme Audit Boards' findings, and the competence of the human resources do not significantly influence the audit results of the financial statements of local governments. The results of this study can contribute both theoretically and practically to the quality of the local governments' financial statements.
\end{abstract}

Keywords: budgets' proportion, human resources, competency, opinions, audit quality. 


\section{INTRODUCTION}

This study aims to empirically examine the effect of (a) the budget's proportion, (b) the effectiveness of the internal auditing system, (c) the follow-up to the Supreme Audit Board's (hereafter SAB) findings, (d) the SAB's opinions from an earlier period, and (e) the competence of the available human resources for interpreting the audit results of local governments' financial statements (LGFS) in Indonesia on the SAB' opinions. The accuracy of the management of local governments' budgets will have an impact on the quality of their financial statements. The management of their budgets becomes very important since each budget lays out a detailed plan for the expenditure and revenue of the local government, so that it can be accountable to the public.

The Minister of Home Affairs in 2010 stated that, at the provincial and district/city levels, on average 56 percent of their total budget was spent on financing the apparatus. This means that, on average, the percentage of the budget for public spending is smaller than that spent on the apparatus to manage it. This suggests that local leaders pay more attention to their own welfare, and the welfare of government officials, than they do to the welfare of society in general. Public spending should directly benefit the public, such as for educational, health, social assistance, and other public facilities. This condition becomes an interesting problem for the allocation of social assistance spending, grants, and the use of any budget surplus, and the disparities between the regions is still very common (Kumorotomo, 2013).

This research is important, and interesting, because the phenomena show that the LGFS which receive fair opinion are still relatively few in number. Moreover, there have not been many studies that analyze the governance and the factors that influence the audit outcomes of the LGFS. The fact that the number of LGFS that obtain an unqualified opinion has become an important event to be analyzed, because the central government had set the LGFS the target of obtaining 50 percent unqualified opinions by 2014. In fact, until the audit of 2011, the unqualified opinions only reached 13 percent (BPK RI, 2014).

In governance, the local leader is the agent who has a responsibility to the stakeholders, as regulated by law. Therefore, the commitment of the local leader becomes very important to achieving good governance. In addition, to conduct this governance and manage the business sector, he/she requires the resources of an organization. Such an organization must be able to optimize the resources under its control to advance itself. Resource-Based Value (RBV) explains that a competitive advantage can be obtained if a firm controls the valuable resources (Gudono 1994). In line with this statement, it can be concluded that to achieve good, quality financial statements, qualified human resources are required.

Jensen and Meckling (1976) define an agency relationship as a contract under which one or more persons (the principal(s)) engage another person (the agent) to perform some service on their behalf which involves delegating some decision making authority to the agent. In the perspective of the agency theory, local leaders are the agents who execute the mandate of their stakeholders. Agency problems occur in all organizations, both in public and private organizations (Stiglitz, 1999). The principalagent framework is a very promising approach to analyzing the commitment to public policy, because it can explain the basic issues of public policy in an integrated framework (Bergman and Lane, 1990). The preparation and implementation of public policy involves fundamental issues of contract, which are due to the asymmetry of information, moral hazards, bounded rationality and adverse selection.

Good governance cannot be separated from the executive and legislative roles. In the context of local government, the roles of the leader and parliament would provide great help in creating good governance performance. The vision and mission of local leaders embodied to all the elements of the local government would play an important role in good governance. In addition, the effectiveness of the functions of the internal 
and external controls will help the realization of the government's accountability.

This study contributes both theoretically and practically to the audit results of the local governments' financial statements as follows. Theoretically, the results of this study can provide empirical evidence that several factors which influence the outcome of the financial statements' audit by the local government were based on the agency theory, bounded rationality, and resource-based values. For local governments, the results of this study can provide inputs about the factors that must be considered when trying to improve the quality of their financial reports. Another contribution is that the results of this study can become inputs to the relevant institutions, for example the Province/ District Inspectorate, and the SAB, to help them in realizing good financial governance by the governments. For practitioners in the public sector, these findings may provide inputs for programs that can be carried out in an effort to improve the quality of the LGFS.

\section{THEORY AND HYPOTHESES DEVELOPMENT}

\section{Good governance}

Corporate governance is the governance of certain organizational forms, namely companies (Zingales, 1997). According to Shleifer and Vishny (1997) corporate governance is a part of the mechanism used to convince the owners of capital that the results which will be obtained will be in accordance with the investments they made. In the context of the public sector, the notion of governance can be defined as the way of managing public affairs (Mardiasmo, 2004).

\section{Agency theory and the proportion of the public sector's budget}

The inception of the agency theory emerged from the existence of the cooperation that divided the owner of the firm and its management (Ross, 1973). The agency theory explains that the relationship between management and principal is set in an employment contract, agreed between the management and the principal (Jensen and Meckling, 1976). The agency relationship exists when the principal employs the agent, and furthermore delegates responsibilities to the agent (Baiman, 1990). The agency theory assumes that an individual, who is fully rational and has clear references, will have the conviction that they will perform at a level that is acceptable (Borner and Sprinkle, 2002). In addition, every individual is judged to be motivated by nothing other than his/her own interests (Baiman, 1990). The function of utility is divided into two, namely monetary and nonmonetary incentives.

With the governance concept, the leader of each region is the agent who has to be responsible to society for what is mandated by the laws of the land and represented by each region's people's representative's house. As a form of responsibility by the leaders to the public, every local leader is obligated to make available the LGFS which have been audited by the SAB. The leaders, who are chosen by the public through elections, are responsible for creating accountability and transparency in the state's financial governance.

To create good local governance, the leaders have to show a high commitment to reaching their organization's goals, which are stated in the regional governments' budgets. The ability of the government to manage their budget is reflected in the regional governments' budgets which describes how the regional government will fund the realization of its development obligations, and to increase equalization and justice through developing all the potential of the region.

Problems occurring in the working relationship between the principal and the agent are caused by two factors: (a) When there is a difference of interests or goals between the principal and the agent, and (b) it is very expensive and difficult for the principal to verify what is actually done by the agent. Differences in the attitudes of the principal and agent in facing and accepting the risks are also influential. Based on the agency theory, the agent is likely to avoid the risks (Eisenhardt, 1989). 
According to Keefer and Khemani (2003) politicians use budget allocations for short term projects that can grab the attention of their electors, and deliver on the promises they made in their campaigns. Since the decisions about funding allocations in the budget are made by a collective, which comprises of the executive and the legislative branches, the instances of misallocations therefore involves the legislative branch. Shleifer and Vishny (1993) stated that in countries in which the government's officials tend to be corrupt, the allocation of resources from the budget is likely to experience distortions. Because of that, expenditure which is easier to use corruptly would receive a larger allocation (Mauro, 1998).

The Ministry of Home Affairs admitted that the budget allocated for central and regional officials was still relatively high. Even the average of the total budget used to finance just the officials in the provinces and regions could reach 56 percent of the total regional governments' budgets. If the budget allocation for the officials is still this high, it means the region leaders are still more concerned with their officials' welfare, rather than with the welfare of their society in general. Thus, it can be concluded that the commitment of the region leaders to the public needs to be reflected by the percentage of the public budget that actually benefits society.

Kumorotomo (2013) said that the role of the state was still less than optimal because of the amount of the state's expenditure which was not effective. As a result of this, it is important to strengthen the accountability of the public budget to improve the effectiveness of the state's expenditure. Until today, public budgets always face budget shortfalls, caused by corruption either of the revenues or the expenditure. Other than the weak effort to collect the taxes that are due, a lot of the public budget's revenues are taken by many misuses of power carried out by government officials. Meanwhile on the expenditure side, political corruption in the budgeting agency, carried out by the political parties' elites, and government officials at the central or regional level, causes the budget losses that can total more than a third of the public budget. There are many forms of fees to be paid which make the amount of real expenditure from the budget continue to decrease in its allocations for social aid expenditure, grant funding, or the remnants of budget funding (Kumorotomo, 2013).

From the perspective of the agency theory, the local leader is the agent of the principal. In the context of budget planning, the agent has the authority to decide the budget proportions, for instance the proportions of the public budget which will be allocated to various projects. However, the agent's opportunistic nature can possibly cause the agent to take benefits from these projects which are funded by the public budget to maximize his/her rewards. If this happens, the possibility of deviations in the budget will be greater. Ineffective financial management by the leaders cause a lot of budget spending with a lack of accountability, so it has a negative impact on the opinions given by the SAB about the fairness of the LGFS. For that reason, based on the perspective of the agency theory, the first hypothesis can be formulated as follows:

H1: The proportions of the public's funds tend to have a negative effect on the results of the opinion about the LGFS in Indonesia.

\section{Effectiveness of the internal audit}

There are three main aspects that support the realization of good governance, namely supervision, control and inspection (Mardiasmo, 2004). Internal audits serve as simple administrative procedures, that mainly consist of a documents examination, an assets calculation, and reports on past events from the various managers. The government, which is moving towards democracy, must demonstrate accountability in its use of public funds and efficiency in its services delivery. Large and complex systems require competence and professionalism, in greater quantities than are needed for an internal audit, and competent resources to be deployed more efficiently to manage and minimize the risks. 
El-Sayed (2011) conducted a study on the function of internal audits in Egypt. The study found that there was a low interaction between the internal auditor and the external auditor in the public sector organizations which were used as the sample, so that many organizations faced difficulties which negatively impacted the effectiveness of their organizational governance. In Indonesia, there are some internal supervisory agencies for the central and local governments. At the district level there is the District Inspectorate, while at the provincial government level there is a Provincial Inspectorate. These provincial inspectorates however, cannot supervise optimally because they simply cannot supervise their provincial governors. In all the ministries in Indonesia, there is an internal oversight agency called the General Inspectorate. However, in practice, they also cannot work optimally. Based on the concept of good governance, the second hypothesis can be formulated as follows:

$\mathrm{H} 2$ : The effectiveness of internal audits tends to have a positive influence on the outcome of the fair opinion of the LGFS in Indonesia.

\section{Follow-up to to the SAB's findings}

There are at least three objectives for hiring the services of an auditor, which are to reduce agency costs, to give a signal to outside parties about the prospects of the company (the signaling hypothesis), and to provide the means for investors to recover some of their investment losses (Chow, Kramer, and Wallace, 1988). One of the incentives to reducing agency costs is by ensuring that the accounting numbers reported are correct and complete. In view of this, the quality of the audit conducted is an important factor because it has a direct impact on the quality of the assurances provided by the auditor (insurance hypothesis).

The SAB's initiative to improve the management and responsibility of the state's finances has not been fully responded to by the central and local governments (BPK RI, 2009). In an examination of the financial statements of the local governments in the second half of 2008 , in terms of preparing their action plans, from the whole 475 local governments listed by the SAB, only 279 of them had prepared an action plan. This means that only 58 percent of the local governments had responded to the SAB's initiative to improve the quality of the LGFS. The SAB also attempted to encourage improvements in financial management by rewarding the central and local government agencies that had some positive achievements in the field of financial governance.

The results of the follow-up examinations at the local level showed that of the 76,733 recommendations (valued at Rp521 trillion), 29,399 recommendations (worth Rp100 trillion) had been acted upon. In the follow-up process, 13,588 recommendations (valued at Rp183 trillion), and 33,746 recommendations (at Rp132 trillion) had not been acted upon. The follow-up to the SAB's findings results is measured by the percentage of the action plan made by each local government, with regard to the SAB's recommendations. Thus, based on the insurance hypothesis, the third hypothesis can be presented as follows:

H3: Follow-up to to the SAB's finding results tends to have a positive influence on the outcome of the fair opinion of the LGFS in Indonesia.

\section{The opinion of the previous period}

Simon (1957), March and Simon (1958) in Bazerman (1994) stated that the individual decision is bounded in its rationality and that we can better understand the decision-making process with the actual explanation rather than the normative one. Auditors, when providing opinions on financial statements, involve the elements of consideration. Consideration refers to the cognitive aspects in the process of decision-making (Bazerman, 1994). Kahneman and Tversky (1973) explained that a man, at the time of making a decision, will base it on a heuristic approach.

This heuristic approach is a rule of thumb used by someone to simplify the information processing in his memory. There are two kinds of heuristic considerations, namely the availability heuristic, and the representativeness 
heuristic. Individuals possess bounded rationality, which states that people tend to make rational decisions, but at the moment important decisions are made, the individual could forget important information relating to the issues to be decided and the relevant criteria relating to the decision to be made. Individual's decisions are bounded by rationality, and we can better understand the decision-making process with the actual explanation, rather than the normative one (Simon, 1957, March and Simon 1958 in Bazerman 1994). The bounded rationality theory says that humans fail to be fully rational because of the following factors (Gudono, 2009): (1) A limited ability to process information, (2) the use of heuristic considerations, and (3) in complex situations people cannot maximize the purpose, but merely achieve satisfying goals.

The fact in Indonesia showed that the LGFS that did not get the fair opinion and received an adverse opinion reached 20 percent in 2011 (BPK RI, 2014). It is certainly a concern for the auditor to provide opinions on the financial statements of the auditing period. In other words, the auditor will be more conservative in giving an opinion. The auditor would expand the control tests when discovering that the earlier opinions were unfair (adverse and disclaimer). Conversely, if the previous year showed fair opinions (unqualified opinion and qualified opinion) the auditor would not extend the control tests because he/she was affected by the fair opinion of the previous period. Therefore, based on the concept of bounded rationality, the fourth hypothesis can be formulated as follows:

H4: The prior period's audit opinions tend to have a positive influence on the outcome of the next period's opinion of the LGFS in Indonesia.

\section{Competence of human resources}

Competitive advantage can be obtained if a firm controls its valuable resources (Gudono, 1994). Resource value is determined by three factors, namely scarcity, need, and appropriateness. In general, the human aspect of the quality initiatives is conceptually significant to improve governance (Mukhtar and Ali, 2011).
Ugboro and Screwdriver (2008) explained that top management's commitment is important to promote a culture of quality building in an organization, and to institutionalize empowerment that involves the division of powers and the delegation of decision-making. The role of the resources that handle financial governance must have sufficient competence in order to provide financial information about the local government in accordance with the government's accounting standards. Human resources are measured by their demographic characteristics, including their levels of education, their educational background, and their experience of the resources involved in the provision of local government financial information. The people in local governments who understand the provision of accounting information will have an impact on the quality of the information presented. Therefore, the concept of the resource-based view of the firm drives the fifth hypothesis which is presented as follows:

H5: The competence of the available human resources tends to have a positive influence on the fair opinion of the LGFS in Indonesia.

\section{RESEARCH METHODS}

\section{Population and sample}

The population of this study is government financial statements from the provinces, districts, and cities in Indonesia. The samples are local government financial reports audited in 2011 by the SAB which were selected by the LGFS. This study combines primary data and secondary data. The primary data were taken from the questionnaires which were used to measure the variables in 2011. Therefore in the observations, the primary data's measurement was aligned with the secondary data, and the samples were selected from the year 2011. This year was selected because of the availability of the respondents, the researchers used the people who attended an event organized by the Assistance Team for Fiscal Decentralization at the Ministry of Finance as the respondents. This event was held in four regions of Indonesia (East Nusa 
Tenggara, South Kalimantan, Yogyakarta and Aceh) which were considered suitable to represent the regions in Indonesia.

\section{The data and variable}

This study used a quantitative approach with secondary data and primary data. The secondary data are the audited financial statements of local governments/cities and provinces in Indonesia, for the year 2011, which were obtained from the SAB. These data contain all the audited LGFS (district/city and province) throughout Indonesia. The data are in the form of percentages of the public budgets and the previous period's audit opinions. The data are used to see the pattern of the LGFS in obtaining an unqualified opinion, a qualified opinion, a disclaimer opinion, and an adverse opinion.

Primary data are the data derived from the results of questionnaires distributed to staff of the Accounting and Reporting of Local Work units of each province, district, and city in Indonesia. For the first stage, a literature review was done to identify the variables that would be included in the questionnaires, and the questionnaires were then distributed to the respondents. The primary data obtained are in the form of demographic details, data on the effectiveness of internal controls, the follow-up to the findings of the SAB, and the human resources available.

This study analyzed the results of the auditors' opinions on the financial statements of local governments in Indonesia. Thus, the samples are LGFS which have been audited by the SAB during 2011. A description of the samples is shown in Table 1 as follows:

Table 1. Sample Description

\begin{tabular}{lc}
\hline \multicolumn{1}{c}{ Annotation } & Total \\
\hline $\begin{array}{l}\text { Number of Audited LGFS 2011 } \\
\text { Less number Audited LGFS 2011 } \\
\text { with incomplete data }\end{array}$ & (86) \\
\hline Final sample of Audited LGFS 2011 & 434 \\
\hline
\end{tabular}

The primary data are the results of the questionnaires that were sent to local governments' finance departments throughout Indonesia. To distribute the questionnaires, the researchers went to the respondents directly, or entrusted their delivery to some friends who were active in projects which cooperated with the local governments, and some were sent by mail. The researchers could meet with the respondents in some regions, such as in Aceh, Yogyakarta, East Nusa Tenggara, South Kalimantan, and Lampung provinces, since they were given the opportunity to cooperate with the Fiscal Decentralization Assistance Team of the Ministry of Finance in assessing the legality of the development Enterprise-Regional Financial Information System. The questionnaire's data can be seen in Table 2 .

Table 2. Questionnaire Description

\begin{tabular}{ll}
\hline \multicolumn{1}{c}{ Annotation } & Total \\
\hline $\begin{array}{l}\text { Number of questionnaires delivered } \\
\text { Less number of questionnaires with }\end{array}$ & 1,000 \\
$\begin{array}{l}\text { incomplete data } \\
\text { Less questionnaires missing/not } \\
\text { returned }\end{array}$ & $(261)$ \\
\hline $\begin{array}{l}\text { Number of questionnaires with } \\
\text { complete data }\end{array}$ & 434 \\
\hline
\end{tabular}

The dependent variable is the opinion issued by the SAB about the LGFS. This opinion is a dichotomous variable, for which the value 1 indicates a fair opinion, and 0 means other than fair. There are four kinds of auditors' opinions, namely an unqualified opinion, a qualified opinion, a disclaimer, and an adverse opinion. In this study, the results of the audit opinion are grouped into two: The fair opinion (unqualified opinion and qualified opinion), and the unfair opinion (disclaimer and adverse opinion).

The independent variables are all factors that potentially affect the quality of the LGFS. The independent variables tested in this study are as follows:

\section{Proportion of public budget (BUDGETPRO).}

This variable indicates the percentage of public expenditure of the total budget. The budget for public spending is the spending which benefits the public in general. This proportion of the budget is measured by looking at the percentage of public expenditure

$$
\text { [ } \left.\frac{\text { public budget }}{\text { total budget }} \times 100 \text { percent }\right] \text {. }
$$


Effectiveness of internal audit (AUDINT). This variable measures the level of effectiveness of the inspectorates' role in the preventive actions and the internal controls of the local government. This variable is measured by looking at the frequency of the inspections carried out by the Provincial Inspectorate based on the results of the survey. The effectiveness of the internal audit was measured with questionnaires and a Likert scale of 1 to 5. Respondents were asked to choose an option to the questions that were asked in the questionnaires. The variable of the effectiveness of the internal audit was measured using a Likert scale of 1 to 5 , the variable of follow-up on the recommendations by the audit board was measured using a percentage (ratio scale), and the human resources were measured using a ratio scale. Specifically for the variables with the Likert scale, before they were included into the measurement model, they had to be converted into a percentage so that they could be measured in a logistic regression model. Scale 5 showed the value of 33 percent, Scale 4 the value of 27 percent, Scale 3 the value of 20 percent, Scale 2 the value of 13 percent, and Scale 1 the value of 7 percent.

Follow-up to to the findings of the SAB (ACTIONPLAN). This variable is measured by the magnitude of the action plan carried out by the local governments to repair the LGFS, based on the completed questionnaires, which can be measured by looking at the percentages of the answers given by respondents.

The previous opinion (PRIOROPIN). This variable is a dichotomous variable, namely: (1) Showing a fair opinion (unqualified and qualified opinion), and (0) indicating an unfair opinion (adverse opinion and disclaimer).

\section{Competency of human resources} (COMPETENCY). This variable measures the competence of the reporting and accounting sections involved in the production of the LGFS information. Those who work in these reporting and accounting sections should have the appropriate expertise and educational backgrounds. The HR aspects are seen against the backdrop of the demographic aspects of the reporting and accounting sections, particularly for their educational backgrounds, based on the results of a survey, measured using a nominal scale. Someone with an accounting background (financial) was given a value of 2 , whereas nonfinancial staff were given a value of 1 . In order to get the data processed with another variable with a ratio scale, the HR variable with its nominal scale was converted into a ratio scale, of which Scale 2 shows the value of 0.67 , and Scale 1 shows the value of 0.33 .

\section{Research model}

$$
\begin{gathered}
\text { OPINION }=a+\text { bIBUDGETPRO }+ \text { b2AUDINT } \\
+b 3 \text { ACTIONPLAN }+ \text { b4PRIOROPIN }+ \\
\text { b5COMPETENCY }+e
\end{gathered}
$$

Notation:

OPINION: This variable indicates the opinion given by the SAB about the LGFS. Opinion is a dummy variable, in this case the value will be 1 for a fair opinion (unqualified or qualified) and 0 for an unfair opinion (adverse opinion or disclaimer).

BUDGETPRO: BUDGETPRO is a variable of the budget proportion, measured by the percentage of public expenditure [(public budget / total budget) $\mathrm{x} 100$ percent]

AUDINT: AUDINT is a variable that measures the effectiveness of the internal audit.

PRIOROPIN: This PRIOROPIN indicates the previous opinions given by the $\mathrm{SAB}$ about the LGFS. Prior opinion is a dummy variable, in this case the value will be 1 for a fair opinion ( unqualified or qualified) and 0 for an unfair opinion (adverse opinion or disclaimer).

ACTIONPLAN: ACTIONPLAN is a variable to measure the magnitude of the action plan on the findings of the $\mathrm{SAB}$ to improve the LGFS.

COMPETENCY: COMPETENCY is a variable of the human resource's capacity to handle local government's finances, as measured from demographic information.

e: error. 
The questionnaire which was developed contained questions that led to the variables tested, including the effectiveness of internal controls, the follow-up on the findings of the $\mathrm{SAB}$, and aspects of the available human resources for the local finance system. The entire questionnaire distributed to the respondents was tested for its validity and reliability.

\section{ANALYSIS OF THE RESULTS}

\section{The respondents' descriptions}

Based on the results of the questionnaires, the respondents can be described by their levels of education, department they work in, their training and experience as follows:

Table 3. The respondents' descriptions based on education levels

\begin{tabular}{lcc}
\hline \multicolumn{1}{c}{ Education } & Frequency & Percent \\
\hline Diploma 3 or under & 80 & 18.4 \\
Bachelor's degree & 217 & 50.0 \\
Master's degree & 137 & 31.6 \\
\hline Total & 434 & 100.0 \\
\hline
\end{tabular}

Table 3 explains that 50 percent of the respondents have a bachelor's degree, 31.6 percent have a master's degree, and 18.4 percent have a diploma 3 or below. Table 4 explains the description of the respondents by educational background.

Table 4. The respondents' descriptions based on educational background

\begin{tabular}{lll}
\hline \multicolumn{1}{c}{ Education Background } & Frequency & Percent \\
\hline Non Financial & 154 & 35.5 \\
Financial & 280 & 64.5 \\
\hline Total & 434 & 100.0 \\
\hline
\end{tabular}

Table 5 shows that 8.1 percent of the respondents have not completed any financial training. A total of 27.4 percent said that they once attended financial training, and 32.9 percent attended it twice, and 31.6 percent attended it 3 times.

Table 6 shows that 35 of the respondents' had a minimum working experience of 1 year, and 40 of them had a maximum of 10 years.
Table 5. Description of the respondents by their participation in training

\begin{tabular}{ccc}
\hline Training & Frequency & Percent \\
\hline 0 & 35 & 8.1 \\
1 & 119 & 27.4 \\
2 & 143 & 32.9 \\
3 & 137 & 31.6 \\
\hline Total & 434 & 100.0 \\
\hline
\end{tabular}

Table 6. Description of the respondents' working experience in finance (accounting)

\begin{tabular}{ccc}
\hline Experience & Frequency & Percent \\
\hline 1 & 35 & 8.1 \\
2 & 45 & 10.4 \\
3 & 39 & 9.0 \\
4 & 35 & 8.1 \\
5 & 40 & 9.2 \\
6 & 54 & 12.4 \\
7 & 49 & 11.3 \\
8 & 54 & 12.4 \\
9 & 43 & 9.9 \\
10 & 40 & 9.2 \\
\hline Total & 434 & 100.0 \\
\hline
\end{tabular}

\section{The feasibility of the logistic regression model}

Before testing the logistic regression, a multicollinearity test was conducted. The VIF value was less than 10 , which meant there were no problems with multicollinearity in the model of the study. To assess the feasibility of the logistic regression models, Hosmer and Lemeshow's goodness of fit test was applied. The results of the feasibility test showed that the Hosmer and Lemeshow's goodness of fit value was 0.295. Due to the value of significance being above 0.05 , our regression model can be used.

\section{Results of analysis}

The logistic regression analysis shows Nagelkerke's R Square value at 0.237 , meaning that the independent variables in the model are able to explain the results of the financial statements' audits' opinions by 23.7 percent, the 
remainder is explained by other variables outside the model.

Table 7. The Analysis of the Logistic Regression

\begin{tabular}{lccc}
\hline \multicolumn{1}{c}{ Variable } & B & Df & Sig. \\
\hline Budgetpro & -1.931 & 1 & 0.004 \\
Audint & 0.145 & 1 & 0.744 \\
Actionplan & -0.004 & 1 & 0.876 \\
Prioropin & 1.828 & 1 & 0.000 \\
Competency & -0.049 & 1 & 0.850 \\
Constant & 0.565 & 1 & 0.643 \\
\hline
\end{tabular}

Value of Nagelkerke R Square: 0.237

The first hypothesis is that the proportion of the public budget tends to negatively affect the results of the fair opinion of the financial statements of the local governments in Indonesia. The statistical tests show the significance of the variable is 0.004 and the coefficient is 1.931. This means the proportion of the public budget negatively affects the fair opinion issued by the SAB. Therefore, the first hypothesis is supported statistically.

This finding is interesting because of the concept that concludes when the percentage of the public budget is high, it indicates that the leaders are committed to the welfare of the society at large, and not only to the welfare of the local government officials, but also to the provision of public service facilities, such as health, education, and other public facilities. In our opinion, a large public budget allocation demonstrates the leaders' commitments to large constituencies to provide or maintain public facilities. However, on the other hand, it is very likely that a large percentage of the public budget will open great opportunities for irregularities, because in fact a lot of the elements will be unjustified. A large public budget proved to be the cause of the poor quality of the local governments' financial statements while attempting to obtain a fair opinion.

If they are related to ethics, the existence of irregularities in the use of the budget shows the ethical violations committed by top management (local leaders). This is in line with what is proposed in law (2011) regarding cheating, that the ethics and morality of top management are positively related to the absence of fraud in their organizations. These results are also consistent with Shleifer and Vishny's study (1993) which stated that in countries in which the government officials tended to be corrupt, the allocations of resources in the budgets were likely to experience irregularities. Mauro (1998) revealed that expenditure which is easier to be corrupted would receive larger allocations. Instead of a greater proportion of the public budget, many are not accountable, which affects the fairness of the financial statements of the local governments. This indicates that based on the perspective of the agency theory, the local leaders make decisions that benefit themselves.

Based on statistical analysis, Table 7 notes that the value of the significance of the effectiveness variable of the internal audit is 0.744 . This indicates that it does not significantly affect the opinion issued by the SAB. Statistically the second hypothesis is not supported. It is probable that the perception of the effectiveness, according to the subject, is not suitable with the perception of the effectiveness of the internal controls according to the auditor. Additionally, it is possible that the execution of the function of control has not run optimally. As revealed by ElSayed (2011) internal auditors' interaction with the external auditors of small public sector organizations reduces the effectiveness of organizational governance. These findings can certainly become a concern to the internal auditor and the external auditors from the government, to avoid the overlapping of districts' financial supervision by the responsible agencies. If the internal controls can run properly, the quality of the LGFS will improve because basically the effectiveness of the internal auditors' role will greatly assist the work of the SAB.

The third hypothesis is that the follow-up to the SAB's findings is likely to positively affect the outcomes of the fair opinion on the LGFS in Indonesia. For the variable of the follow-up to the SAB's recommendations, Table 7 notes that the significance value is 0.876 . Because the 
significance value is greater than alpha 0.05 , it means the third hypothesis, which states that the follow-up to the auditors' recommendations is likely to affect the result for a fair opinion, is not supported. Recommendations given (a letter from the management) cannot guarantee that the financial statements are free from errors or misinformation. It is probable that there are different interpretations of the recommendations given. One of the problems of regulation in Indonesia is the difference between the interpretations of a law and the regulations under it. These multi-interpretations can further cause various deviations from the original regulatory purpose.

The fourth hypothesis is that the previous period's audit opinion tends to positively affect the auditor's opinion for the results of the next period of the LGFS. Table 7 shows that the variable of the previous opinion shows the significance value of 0.000 with the coefficient value of 1.828 . This suggests the hypothesis stating that the previous opinion affects the outcome of the next period's opinion on the LGFS is statistically supported. This means the previous period's opinion can be used as a benchmark for the current opinion. Therefore, if the local financial statements obtained a fair opinion last year, an examination of that year does not need to be expanded. In connection with the provision of the opinion given by the $\mathrm{SAB}$, there is also the element of consideration involved, whereby an individual's considerations are bounded by their rationality. This is consistent with the bounded rationality theory which states that people tend to want to make a rational decision, but at the moment any important decision must be made, that individual could forget important information relating to the issues to be decided, and the relevant criteria relating to the decision to be made.

Preparation of the GFS has been regulated by government regulations, and there have been technical implementation guidelines and clear instructions and standards issued. Reporting and accounting resources that have a financial background should have better knowledge than those that do not have any financial background.
The fifth hypothesis is that the competency of human resources is likely to positively affect the results of a fair opinion on the LGFS. Table 7 shows that the value of significance for the human resources' competency is 0.850 . Since this value is more than alpha 0.05 , statistically the fifth hypothesis is not supported. Conceptually, the results of the observation should be in line with the results of the research done by Mukhtar and Ali (2011) which stated that the human aspect of initiative is conceptually significant for improving governance. However, statistically the results of this study indicated that the competence of the human resources had no significant effect on the results of the LGFS's opinion. These results were very likely due to the implementation of financial governance rules which were not followed correctly. Other causes could also have had an effect since there are many types of systems that are applicable to the preparation of the LGFS. For example, in the preparation of the LGFS there are lots of reporting systems used, such as SIPKD, SIMDA, SIMAKDA, SIMKUDA, and other applications.

In addition, a number of revisions or new regulations have been issued by the government or other public organizations. For example, in the field of public finance, reformation of the regulations began with the enactment of Law No. 17 of 2003, which was followed by the inception of Regulation No. 13 of 2006, which was revised back to Regulation No. 59 of 2007. Although it has been revised, various problems associated with these regulations remain (Bastian, 2011). The phenomenon of regulatory reformations which never ends has made the regulations for financial authorities at the regional level blurred.

\section{CONCLUSION}

The fact that there are still few qualified opinions on the financial statements of local governments has surely become an issue of interest. This condition indicates that the governments' financial governance is not running optimally. This study used a sample of 434 local governments' financial reports in 
Indonesia, to measure the factors that affect the outcome of local governments' financial statements' opinions. The results of this study show that the proportion of the public budget has significant negative effects on fair opinions of the LGFS. This implies that a greater public budget allocation will likely create a negative impact on the quality of the financial statements because it cannot be properly accounted for. These results are in line with the agency theory which confirms that basically the agents act rationally, based on their own personal interests. Other findings that previous opinions affect the fairness of the financial statement's opinion imply that the previous opinions are used as the basis of the audit boards' determination of the local governments' financial reports. If the previous period's opinion was unfair, the audit board will be more conservative in assessing the fairness of the financial statements of the new year. Vice versa, if the opinion of the previous period was fair, the auditor would not extend the disclosure of the financial statements for that year. The findings are in line with the nature of auditors' bounded rationality in making a decision. Furthermore, the internal controls, the follow-up actions to the audit boards' findings, and the competence of the human resources do not significantly influence the results of the local governments' financial statements' opinions.

\section{Limitations and suggestions}

There are some limitations to this study. This study only analyzed five factors suspected to affect the outcome of the local governments' financial statements' opinions, whereas there might still be other influential factors. Future studies can incorporate the other factors that may affect the results of this opinion, such as the local leaders' ethics. This study combines secondary data and primary data to analyze the effect of the demographics on the results of the auditors' opinions, so it can only capture the effect of the independent variables on the results of the opinions for 2011.

\section{REFERENCE}

Bazerman, Max H., 1994. Judgment in Managerial Decision Making. John Wiley $\&$ Sons, Inc. Singapore.

Badan Pengawasan Keuangan dan Pembangunan (BPKP), 2005. Modul Pelatihan Evaluasi Laporan Akuntabilitas Kinerja Instansi Pemerintah Seri : PP/LAN-BPKP/2005.

Badan Pemeriksa Keuangan Republik Indonesia (BPK RI), 2007. Peraturan BPK Nomor 1 Tahun 2007 tentang Standar Pemeriksaan Keuangan Negara.

, 2009. "Siaran Pers BPK: Laporan Keuangan Daerah Makin Memburuk", http://www.bpk.go.id/web/files/2009/05/pen yerahan-ihps-ii-2008-ke-dpd1.pdf.

----------, 2014. "Hasil Pemeriksaan BPK Semester I Tahun 2014", http:// bpk.go.id/ news/ hasil-pemeriksaan-bpk-semester-itahun-2014.

Baiman, S., 1990. "Agency research in managerial accounting: A second look". Accounting, Organizations and Society, 15 (4), 341-371.

Bastian, Indra, 2011. Akuntansi Sektor Publik di Indonesia. BPFE-Yogyakarta.

-------, 2011. Akuntansi Sektor Publik: Suatu Pengantar. Edisi Ketiga, Penerbit Erlangga.

Bergman, Michael and Jan-Erik Lane, 1990. "Public policy in a principal-agent framework". Journal of Theoretical Politics, 2 (3), 339-352.

Chow, C.W., Kramer, L. and W.A. Wallace, 1988. The Environment of Auditing in Research Opportunities in Auditing: The Second Decade. (A.R. Abdel-Khalik and I. Solomon, editors). Sarasota, FL: American Accounting Association: 155-183.

El-Sayed, Ebaid Ibrahim, 2011. "Internal audit function: An exploratory study from Egyptian listed firms". International Journal of Law and Management, 53 (2): 108-128.

Eisenhardt, K. M., 1989. "Agency Theory: An Assessment and Review". Academy of Management Review, 14 (1), 57-74. 
Forum of Corporate Governance in Indonesia (FCGI), 2001. Corporate Governance, Tata Kelola Perusahaan, Jilid I edisi ke-2.

Gudono, 2009. Teori Organisasi, Edisi 1, Pensil Press, Daerah Istimewa Yogyakarta. , 2012. Teori Organisasi, Edisi 2, BPFE, Yogyakarta.

Hayes, Rick, Roger Dassen, Arnold Schilder, and Philip Wallage, 2005. Principles of Auditing: An Introduction of International Standards on Auditing. Second Edition, Prentice Hall.

Instruksi Presiden Republik Indonesia No. 4 Tahun 2011 Tentang Percepatan Peningkatan Kualitas Akuntabilitas Keuangan Negara. Lembaran Negara Republik Indonesia Tahun 2011.

Jensen, Kevan L. and Jeff L. Payne, 2005. "Audit Procurement: Managing Audit Quality and Audit Fees in Response to Agency Costs". Auditing: Journal of Practice \& Theory, 24 (2), 27-48.

Jensen, M. and Mecking, W., 1976. "Theory of The Firm: Managerial Behaviour, Agency Costs and Ownership Stucture". Journal of Financial Economics, 3 (4), 305-360.

Kahneman, D., and Tversky, A., 1973. "On Psychology of Prediction". Psychological Review, 80, 237-251.

Kumorotomo, Wahyudi, 2013. "Tingkatkan efektivitas belanja negara dengan penguatan akuntabilitas anggaran publik", .http://www.ugm.ac.id/id/berita/8318.

Law, Philip, 2011. "Corporate governance and no fraud occurrence in organizations: Hong Kong evidence". Managerial Auditing Journal, 26 (6), 501-518

Lawton, A., McKevitt, D. and Millar, M., 2000. "Coping with ambiguity: Reconciling external legitimacy and organizational implementation in performance measurement". Public Money \& Management, 20 (3), 13-19.

Mardiasmo, 2004. Akuntansi Sektor Publik. Edisi 2, Penerbit Andi Yogyakarta. -,2008. Workshop Kajian Implementasi Standar Akuntansi Pemerintahan (PP 24/2005): Kendala, Tantangan dan Solusi, Jakarta.
Mauro, 1998. "Corruption and the composition of government expenditure". Journal of Public Economics, 69, 263-279.

Mukhtar, Ramlah, and Noor Azman Ali, 2011. "Quality governance of human aspects of quality initiatives in the public service sector". Current Issues of Business and Law, 6 (1), 111-128.

Peraturan Pemerintah No. 58 Tahun 2005 Tentang Pengelolaan Keuangan Daerah. Lembaran Negara Republik Indonesia Tahun 2005

Peraturan Pemerintah No. 24 Tahun 2005 Tentang Standar Akuntansi Pemerintahan. Lembaran Negara Republik Indonesia Tahun 2005

Undang-undang No. 17 Tahun 2003 Tentang Keuangan Negara. Lembaran Negara Republik Indonesia Tahun 2003.

-No. 1 Tahun 2004 Tentang Perbendaharaan Negara. Lembaran Negara Republik Indonesia Tahun 2004.

Undang-undang No. 15 Tahun 2004 Tentang Pemeriksaan Pengelolaan dan Tanggung jawab Keuangan Negara. Lembaran Negara Republik Indonesia Tahun 2004.

Undang-undang No. 15 Tahun 2006 Tentang Badan Pemeriksa Keuangan. Lembaran Negara Republik Indonesia Tahun 2006.

Undang-undang No. 33 Tahun 2004 Tentang Perimbangan antara Keuangan Pemerintah Pusat dan Pemerintah Daerah. Lembaran Negara Republik Indonesia Tahun 2004.

Ross, A Stephen. 1973. "The Economic Theory of Agency: The Pricipal's Problem". American Economics Review, 63 (2), 134139.

Sawyer, Lawrence B., Mortimer D. Dittenhofer, James H. Scheiner, 2005. Sawyer's Internal Auditing, Buku 1 Edisi 5, Salemba Empat, Jakarta.

Shleifer, A., and Robert W. Vishny, 1993. "Corruption". Quarterly Journal of Economic, 108, 599-617.

1997. "A survey of corporate governance". Journal of Finance, 737-783.

Stiglitz, Joseph E., 1999. Economics of the Public Sector. Third edition. New York: W.W. Norton and Company. 
Ugboro, I. O., Obeng, K., 2000. “Top management leadership, employee empowerment, job satisfaction, and customer satisfaction in TQM organizations: An empirical study". Journal of Quality Management, 5, 247272.
Zingales, Luigi. 1997. "Corporate governance", National Bureau of Economic Research Working Paper 6309,

>http://www.nber.org/papers/w6309. 